www.jmscr.igmpublication.org

Impact Factor (SJIF): 6.379

Index Copernicus Value: 71.58

ISSN (e)-2347-176x ISSN (p) 2455-0450

crossrefDOI: https://dx.doi.org/10.18535/jmscr/v6i7.190

Journal Of Medical Science And Clinical Research

IGM Publication

An Official Publication of IGM Publication

\title{
A Study on the Effectiveness of a Structured Information Booklet on Patients \& Caregivers Knowledge, Attitude and Practice Regarding Prevention of Complications Due to Immobilisation
}

\author{
Authors \\ Dr Rabi Narayan Dhar ${ }^{1}$, Dr Bijay Kumar Lamay ${ }^{2 *}$, Dr Rasmiranjan Dash ${ }^{3}$ \\ ${ }^{1}$ Associate Professor, Dept of Orthopaedics, VIMSAR, Burla \\ ${ }^{2}$ Assistant Professor, Dept of Orthopaedics, VIMSAR, Burla \\ ${ }^{3}$ Post graduate student \\ *Corresponding Author \\ Dr Bijay Kumar Lamay \\ Email: sikatananda@yahoo.in
}

\begin{abstract}
Introduction: Immobilization is a most common treatment provided to injured patients admitted to the orthopedic. Immobilized patients have the highest risk of complications and death associated with it.

Objective: 1.To assess the level of knowledge, attitude, perception and practice of immobilized patients and their care givers regarding prevention of complications following their immobilization. 2.To find the relationship between the different areas of the knowledge domain regarding complications of immobilization between the primary care givers and the patients.

Methodology: Type of study: A cross sectional, hospital based study.

Statistical Analysis: The data after collection, compilation was analyzed by SPSS.

Observation \& Discussion: About 66(64.08\%) of patients had inadequate knowledge about different aspects of immobilization and its complication.57(55.34\%) had inadequate knowledge on different aspects of immobilization for prevention of complication. $2 \%$ of caregivers were only aware about pharmacological thrombophlebitis but very less i.e. $1.2 \%$ was aware about relevant information on VTE. Out of 103 caregivers (98\% were family members and $2 \%$ unrelated) filled up the questionnaire which enquired about the issues related to pressure ulcer prevention \& treatments. In the pretest only $3.5 \%$ individuals knew actually what pressure ulcer was, $2.3 \%$ of caregivers were aware about the cause of pressure ulcer and $95 \%$ were not able to identify the risk factors of pressure ulcer.
\end{abstract}

\section{Introduction}

Immobility means impairment or inability to move or even change in position of the body independently or movement of any medical cause or reason is restricted. Immobilization is a most common practice in injured patients admitted to the orthopedic ward as inpatient and it is one of the best modality of treatment for recovery. However, it is seen that immobilized patients have the highest death complications. The main cause of injury requiring immobilization is mainly due to road traffic incidents. Road traffic incident in India in the year 2016 was 4,80, 652 and fatalities was $3 \%$ during the same period ${ }^{1}$. Venous 
thromboembolism (VTE), which includes (DVT) deep vein thromboembolism, pulmonary thromboembolism, pressure ulcer are the complications of long periods of immobilization in the hospital and may be serious cause of mortality and morbidity. This impact is preventable if appropriate strategies on VTE and pressure ulcer prevention, early ambulation, reporting of the warning danger early signals of VTE is timely adopted and addressed.

An orthopedic patient is more vulnerable to the side effects of long term immobilization hence this particular study was undertaken with the following aims and objectives:

\section{Objective}

1. To assess the level of knowledge of immobilized patients and their care givers regarding prevention of complications following their immobilization.

2. To assess the attitude, perception and practice of immobilized patients and their care givers regarding prevention of complications following their immobilization.

3. To find the relationship between the different areas of the knowledge domain regarding complications of immobilization between the primary care givers and the patients.

4. To disseminate developed information booklet cum guide on different aspects of prevention of complication of immobilization in orthopedic patients.

\section{Methods}

Type of study: A cross sectional, hospital based with interventional approach was done to meet the objectives of this study.

Place of study: Department of Orthopedics, VIMSAR, Burla, Odisha.

Period of study: May 2015 to April 2018.

Study participants: This study was conducted in the department of Orthopedics and included 103 patients who were admitted in the department of Orthopedics at VIMSAR, Burla and who were advised absolute bed rest and so labeled as bedridden. A total 103 patients fulfilled the study criteria. All the patients were immobilized due to fracture pelvis or multiple fractures or spinal injury and so had undergone treatment as surgical procedure or were on conservative cast management.

Study Criteria: The patients and care givers of immobilized patients who were willing to cooperate and undertake the interventional study of assisted self directed learning by a developed information guide cum booklet. The informed consent was taken from the patients as well as care givers. A proforma was developed by which data was collected regarding different variables like age, sex, socio demographic profile diagnosis at admission, area of residency, education, socio economic status, duration hospital stay. Questions on different aspects of immobilization like basic concepts, role of a care giver, recording of vital signs, feeding, bed making, diaper change, posture change, physiotherapy, administration of medication was evaluated.

The data was compiled; tabulated analyzed and different statistical methods were applied.

\section{Exclusion criteria}

- All ambulatory patients i.e., who get out of bed without assistance

- Terminally ill patients

- Patients in whom immobilization was not required and their care givers

Study tool: A structured information booklet cum guide was prepared in consultation with faculties of Orthopedics, Neurology and Physiotherapy. The schedule cum questionnaire was prepared and validated by a faculty of Orthopedics, Neurology at VIMSAR, Burla. The booklet comprised of general concept of immobilization and the reasons for the occurrence of the common complications, methods to be adopted for prevention of different complications. There are different scales and standards in health care of chronically ill patients which resulted in improvement of pressure ulcer preventions and treatment in institutional care. However, awareness and preparation of family members and their care givers is essential who 
will provide home care after discharge from the hospital. So there was a need for preparation and implementation of an educational intervention for these immobilized patients and their care givers. This study also highlights the need to strengthen the role of an information booklet to provide patient education about VTE.

Statistical Analysis: The data after collection, compilation was analyzed by SPSS.

\section{Observation}

Table-1 Different Aspects of knowledge domain regarding immobilization and its complication among participants

\begin{tabular}{|c|c|c|}
\hline $\begin{array}{lrr}\text { Different } & \text { aspects } & \text { of } \\
\text { immobilization } \quad \& & \text { its } \\
\text { complications } & & \\
\end{array}$ & $\begin{array}{l}\text { Patient } \\
\text { (Correct } \\
\text { response) }\end{array}$ & $\begin{array}{l}\text { Care giver } \\
\text { (Correct } \\
\text { response) }\end{array}$ \\
\hline $\begin{array}{l}\text { Basic concept of } \\
\text { immobilization }\end{array}$ & & \\
\hline Yes & & \\
\hline No & & \\
\hline Awareness about DVT & & \\
\hline Yes & & \\
\hline No & & \\
\hline $\begin{array}{l}\text { Awareness about pulmonary } \\
\text { immobilization }\end{array}$ & & \\
\hline Yes & & \\
\hline No & & \\
\hline S/S of DVT & & \\
\hline $\begin{array}{l}\text { Different prevention modalities } \\
\text { of DVT }\end{array}$ & & \\
\hline $\begin{array}{lll}\text { Heard about } & \text { venous } \\
\text { thromboembolism } & \\
\end{array}$ & & \\
\hline Friends & & \\
\hline Family member & & \\
\hline Health care provider & & \\
\hline Media & & \\
\hline $\begin{array}{l}\text { Aware about drugs given to } \\
\text { prevent thrombophlebitis }\end{array}$ & & \\
\hline Yes & & \\
\hline No & & \\
\hline $\begin{array}{l}\text { Aware about risk factors of } \\
\text { DVT }\end{array}$ & & \\
\hline Yes & & \\
\hline No & & \\
\hline $\begin{array}{l}\text { Chance of development of } \\
\text { pulmonary embolism in patient } \\
\text { with DVT }\end{array}$ & & \\
\hline Yes & & \\
\hline No & & \\
\hline $\begin{array}{l}\text { Duration of absolute stay in } \\
\text { bed in directly related to DVT }\end{array}$ & & \\
\hline Yes & & \\
\hline No & & \\
\hline $\begin{array}{l}\text { Treatment of VTE - decreasing } \\
\text { venous stasis by physiotherapy } \\
\text { of leg exercise, leg elevation }\end{array}$ & & \\
\hline Yes & & \\
\hline No & & \\
\hline
\end{tabular}

\begin{tabular}{|l|l|l|}
\hline Elastic stocking necessary & & \\
\hline Yes & & \\
\hline No & & \\
\hline Contracture of muscle & & \\
\hline $\begin{array}{l}\text { Muscle atrophy due to disuse of } \\
\text { joint/ muscle }\end{array}$ & & \\
\hline Yes & & \\
\hline No & & \\
\hline $\begin{array}{l}\text { Heard about Risk factors of } \\
\text { contractures / muscle atrophy }\end{array}$ & & \\
\hline Yes & & \\
\hline No & & \\
\hline $\begin{array}{l}\text { Joints to be placed at neutral } \\
\text { portion }\end{array}$ & & \\
\hline Yes & & \\
\hline No & & \\
\hline $\begin{array}{l}\text { Immobilization can lead to } \\
\text { decrease in bone mass }\end{array}$ & & \\
\hline Yes & & \\
\hline No & & \\
\hline GI Complication & & \\
\hline Loss of appetite & & \\
\hline $\begin{array}{l}\text { Decreased peristalsis, decreased } \\
\text { intake of fluids }\end{array}$ & & \\
\hline $\begin{array}{l}\text { Decrease in fat stores and } \\
\text { glucose tolerance }\end{array}$ & & \\
\hline Complications & & \\
\hline Pressure ulcer & & \\
\hline Most common site (location) & & \\
\hline Risk factors of pressure ulcer & & \\
\hline Mode of prevention & & \\
\hline Treatment of pressure ulcer & & \\
\hline Ulcer type & & \\
\hline 2 hourly position change in bed & & \\
\hline Care of the skin, bladder, bowel & & \\
\hline Need of early rehabilitation & & \\
\hline Passive mobilization Exercises & & \\
\hline $\begin{array}{l}\text { Necessity of medical care and } \\
\text { ritative care }\end{array}$ & & \\
\hline
\end{tabular}

Out of the total 103 patients, about 34\% (35) of them belonged to 61yrs and above whereas amongst caregivers of patients 33(32\%) belonged to (31-40) yrs of age. Regarding the gender, there was male predominance in patients as well as amongst caregivers. The education amongst caregivers was $28.16 \%$ till primary school level. Regarding occupation about 17 caregivers i.e. $16.5 \%$ were doing private service whereas about $26(25.25 \%)$ of patients were unskilled laborer by profession. (table-2) 
Table 2 Socio-demographic variables of study subjects and their caregivers

\begin{tabular}{|c|c|c|c|c|c|}
\hline \multirow[t]{2}{*}{ SI. No. } & \multirow[t]{2}{*}{ Demographic Variable } & \multicolumn{2}{|c|}{ Patient $(n=103)$} & \multicolumn{2}{|c|}{ Care Giver $(\mathrm{n}=103)$} \\
\hline & & No & $\%$ & No & $\%$ \\
\hline \multirow[t]{6}{*}{1.} & Age in Years & & & & \\
\hline & $20-30$ & 7 & 6.79 & 22 & 21.36 \\
\hline & $31-40$ & 20. & 19.42 & 33 & 32.01 \\
\hline & $41-50$ & 20 & 19.42 & 7 & 6.79 \\
\hline & $51-60$ & 21 & 20.39 & 21 & 20.39 \\
\hline & 61 and above & 35 & 33.98 & 20 & 19.42 \\
\hline \multirow[t]{3}{*}{2} & Gender & & & & \\
\hline & Male & 72 & 69.91 & 72 & 69.91 \\
\hline & Female & 31 & 30.09 & 31 & 30.09 \\
\hline \multirow[t]{7}{*}{3.} & Educational Qualification & & & & \\
\hline & Illiterate & 22 & 21.36 & 19 & 18.45 \\
\hline & Just literate & 06 & 5.83 & 10 & 9.71 \\
\hline & Primary & 27 & 26.21 & 29 & 28.16 \\
\hline & Secondary & 14 & 13.59 & 15 & 14.56 \\
\hline & Higher Secondary & 23 & 22.33 & 16 & 15.53 \\
\hline & Graduate and above & 11 & 10.68 & 14 & 13.59 \\
\hline \multirow[t]{8}{*}{4.} & Occupation & & & & \\
\hline & Unemployed & 17 & 16.50 & 12 & 11.65 \\
\hline & Labour class & 12 & 11.65 & 18 & 17.46 \\
\hline & Skilled & 17 & 16.50 & 30 & 29.13 \\
\hline & Unskilled & 26 & 25.25 & 14 & 13.59 \\
\hline & Private (Semi) & 12 & 11.65 & 17 & 16.50 \\
\hline & Government (Semi) & 06 & 5.83 & 8 & 7.77 \\
\hline & Self employed & 13 & 12.62 & 4 & 3.88 \\
\hline \multirow[t]{3}{*}{5.} & Marital Status & & & & \\
\hline & Married & 57 & 55.34 & 41 & 39.81 \\
\hline & Unmarried & 46 & 44.66 & 62 & 60.19 \\
\hline
\end{tabular}

Table 3 Frequency distribution of the study subjects on their level of knowledge regarding prevention of complication

\begin{tabular}{|l|c|c|c|}
\hline SI. No & $\begin{array}{c}\text { Knowledge score } \\
\text { frequency }\end{array}$ & No & \% \\
\hline 1 & Adequate $(21-40)$ & 37 & 35.92 \\
\hline 2 & Inadequate $(0-20)$ & 66 & 64.08 \\
\hline \multicolumn{2}{|c|}{ Total } & 103 & \\
\hline
\end{tabular}

Table-3 depicts the different knowledge scores amongst patients. About 66(64.08\%) of patients had inadequate knowledge about different aspects of immobilization and its complication.

Table 4 Frequency distribution of the care giver on their level of knowledge regarding prevention of complication

\begin{tabular}{|l|l|l|l|}
\hline Sl. No & Knowledge domain score & No & \% \\
\hline 1 & Adequate $(21-40)$ & 46 & 44.66 \\
\hline 2 & Inadequate $(0-20)$ & 57 & 55.34 \\
\hline & Total & 103 & \\
\hline
\end{tabular}

Table-4 provides information about the frequency distribution of the caregivers on the level of knowledge regarding prevention of complication. It was ascertained that $57(55.34 \%)$ had inadequate knowledge on different aspects of immobilization for prevention of complication.

Table 5 Percentage distribution of patients on the level of practice regarding prevention of complications

\begin{tabular}{|l|c|c|c|}
\hline Sl. No & Practice Skills score & No & $\%$ \\
\hline 1 & Adequate $(16-30)$ & 33 & 32.04 \\
\hline 2 & Inadequate $(0-15)$ & 70 & 67.96 \\
\hline \multicolumn{2}{|c|}{ Total } & 103 & \\
\hline
\end{tabular}

Table 6 Percentage distribution of the care giver on the level of practice regarding prevention of complication

\begin{tabular}{|l|l|l|l|}
\hline Sl. No & Practice Skills score & No & $\mathbf{\%}$ \\
\hline 1 & Adequate $(16-30)$ & 38 & 36.89 \\
\hline 2 & Inadequate $(0-15)$ & 65 & 63.11 \\
\hline & Total & 103 & \\
\hline
\end{tabular}




\section{JMSCR Vol||06||Issue||07||Page 1144-1151||July}

Table 7 Mean Rank order \& spearman's correlation of coefficient ' $r$ ' of different levels of knowledge domain areas in regard to complication following immobilization between the patients $\&$ their care givers.

\begin{tabular}{|l|c|c|c|c|c|}
\hline \multirow{2}{*}{ Different complication due to immobility } & \multicolumn{2}{|c|}{ Patient } & \multicolumn{2}{c|}{ Care Giver } & Spearman's correlation \\
\cline { 2 - 5 } & Mean & Order & Mean & Order & \\
\hline Concept of immobilization & 7.40 & 1 & 7.30 & 1 & \\
\hline Pressure score / ulcer & 1.60 & 6 & 2.80 & 6 & \multirow{2}{*}{$0.87^{*}$} \\
\hline Deep Vein thrombosis (DVT) & 1.21 & 7 & 2.60 & 7 & \\
\hline Hypostatic pneumonia & 3.41 & 4 & 3.97 & 5 & \\
\hline Constipation & 3.27 & 5 & 4.10 & 4 & \\
\hline Contractures & 5.81 & 2 & 5.99 & 3 & \\
\hline G.I. complication & 5.19 & 3 & 6.10 & 2 & \\
\hline
\end{tabular}

It is significant at 0.05 level of significance

Table 8 Type of Fracture / Injury of patients admitted and in need of immobilization

\begin{tabular}{|l|c|c|}
\hline Type of fracture / Injury in patients & No. & $\%$ \\
\hline \#Pelvic Bone & 20 & 19.42 \\
\hline Comminuted \# of long bone & 8 & 7.77 \\
\hline \# Vertebra & 18. & 17.48 \\
\hline \#Pelvis + long bone & 23 & 22.33 \\
\hline \#Pelvis \& \#Vertebra & 25 & 24.27 \\
\hline Spinal Injury & 9 & 8.73 \\
\hline Total & 103 & $100(\%)$ \\
\hline
\end{tabular}

Table 9 Type of spinal Injury patients admitted to the ward

\begin{tabular}{|l|c|c|}
\hline Type of Spinal Injury & $\mathrm{N}=9$ & $100(\%)$ \\
\hline Cervical Spine & 2 & 22.22 \\
\hline Thoracic & 1 & 11.11 \\
\hline Lumbar & 4 & 44.45 \\
\hline Thoraco lumbar & 2 & 22.22 \\
\hline
\end{tabular}

Figure 1 Percentage Distribution of Patients admitted in Orthopedic ward with duration of immobilization

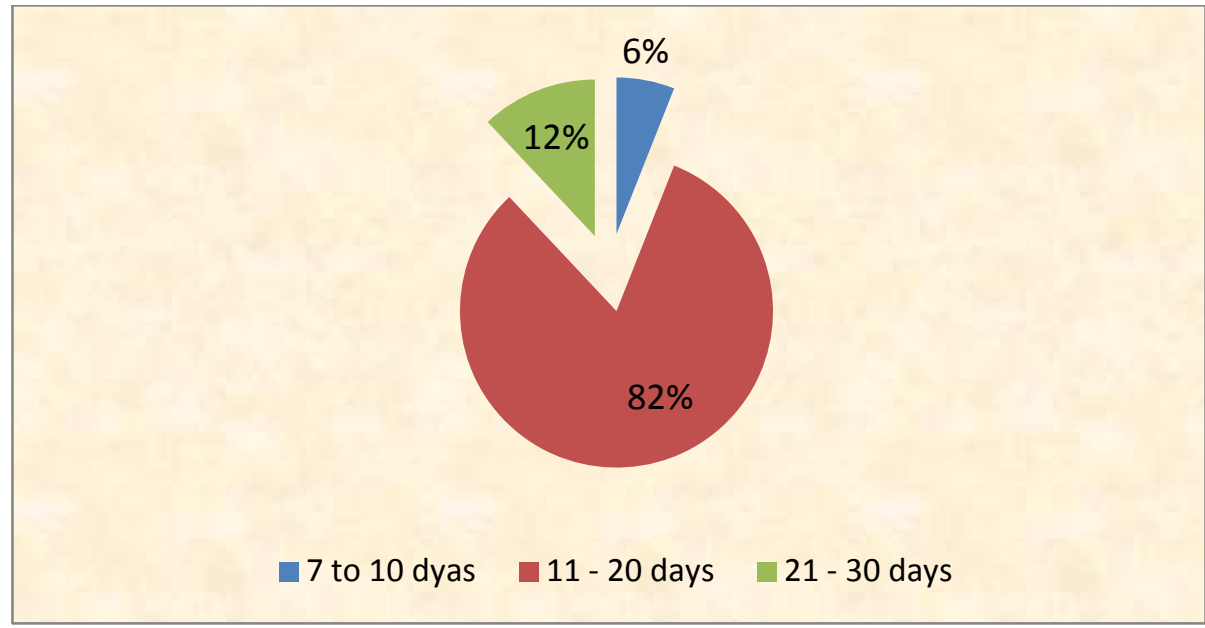

Figure 2: Percentage distribution of patients on the attitude regarding prevention of complications.

$$
\text { Adequate Practice Inadeuate Practice }
$$


Figure 3: Percentage distribution of Caregiver of patients on the attitude regarding prevention of complications

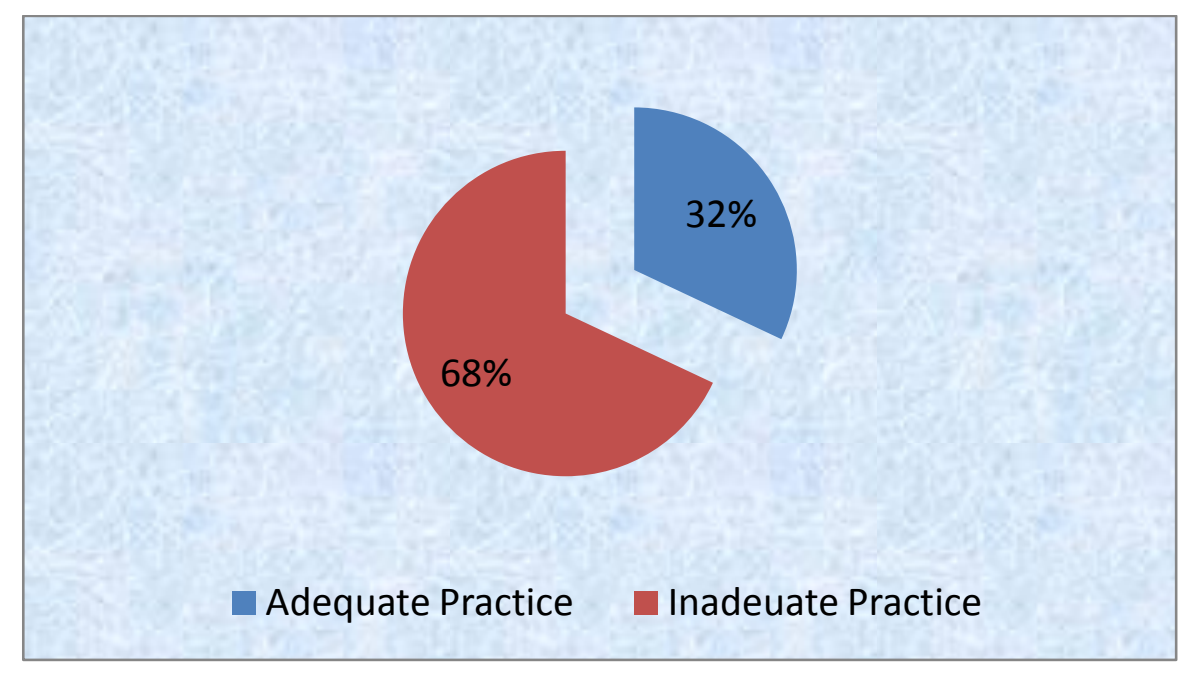

Table 10 : Average Score on True / False Test

\begin{tabular}{|l|c|}
\hline $\begin{array}{l}\text { Prevention of skin ulcer \& management } \\
\text { of Stage I \& II pressure ulcer }\end{array}$ & $\%$ \\
\hline Pretest group average Score & $77.5 \%$ \\
\hline Post test group average score & $89.5 \%$ \\
\hline Pretest and post test improvement & $12 \%$ \\
\hline
\end{tabular}

Table 11: Average scores on test using charts and models

\begin{tabular}{|l|c|}
\hline $\begin{array}{l}\text { Ulcer type recognition \& staging of } \\
\text { pressure ulcer }\end{array}$ & \\
\hline Pretest group average Score & $36.66 \%$ \\
\hline Posttest group average score & $68.6 \%$ \\
\hline Pretest and post test improvement & $32 \%$ \\
\hline
\end{tabular}

\section{Discussion}

The participants reported having heard about VTE more frequently from friends, family or the media than from heath care providers, including nurse. $2 \%$ of caregivers were only aware about pharmacological thrombophlebitis but very less i.e. $1.2 \%$ were aware about relevant information on VTE. The pretest findings suggested that patients \& caregivers required more and further information on VTE during their hospitalization to enhance their involvement in VTE prevention. There was a need to provide a written, patient directed information that would address their lack of involvement / practice, knowledge, attitude regarding DVT. Out of 103 caregivers (98\% were family members and $2 \%$ unrelated) filled up the questionnaire which enquired about the issues related to pressure ulcer prevention \& treatment.
In the pretest only $3.5 \%$ individuals knew actually what pressure ulcer was, $2.3 \%$ of caregivers were aware about the cause of pressure ulcer and $95 \%$ were not able to identify the risk factors of pressure ulcer. Majority of the caregivers did not know the essential principles of prevention including devices used in pressure ulcer prevention, about the water bed / air bed mattress nor about the dressings used for treatment. $85 \%$ of the caregiver never received any information about different methods of pressure ulcer prevention and only $7 \%$ received such information from nurses which reflects low involvement of professional staff. Pagadpally et al (2003) in a study revealed that common mode of injury was fall from height followed by road traffic accident. ${ }^{2}$ Following prolonged bed rest to restricted patients traction, shearing during movement promotes abrasion, skin injuries and breakdown leading to pain, infection \& other complications. Contracture also causes capillary occlusion at bony prominences. As much as $50 \%-70 \%$ of all pressure ulcers are related to untreated contractures. Contractures are fixed deformities of the joints which are due to immobilization. As contractive tissue and muscle in the body is dynamic in nature and constantly being replaced and recognized through a series of phases of healing. ${ }^{3}$ 
Disused weakness is reversed at a rate of only $6 \%$ per week using submaximal exercise. ${ }^{4}$ According to Mac Dougall JD et al, there can be reduction in muscle strength, metabolic activity and circulation due to complete immobilization ${ }^{5}$. Sarmiento and Latta et al in his study has shown that after stabilization and early callus formation, joints associated with the fracture can be mobilized if properly bracing is done in order prevent displacement. $^{6}$

While immobilizing the joints should be kept in neutral protection so that the opposing muscle are at equal tension and length.

The self instructional booklet comprised of various types of injury, DVT, complications, methods of prevention.

\section{- General definition}

- Reason for patients to stay in bed could be as follows.

- Multiple trauma

- \# spine

- Paralysis

- Multiple causes.

- Common Complications like

- Muscles weakness / atrophy

- Muscle shortness

- Pressure sores / ulceration

- Lung infection

- VTE

- Osteoporosis

\section{Conclusion}

Patients are benefitted by patient information \& training .Information on the patients situation, his / her needs and his/her future complications should be provided to the patient or to his / her family. Information brochures is used $\&$ it is by the booklet and our assistance, that the patients or his / her family member is taught how to do basic exercise by themselves. There are also different scales and standards in health care of chronically ill patients which resulted in improvement of pressure ulcer prevention and treatment in institutional care.
However, awareness \& preparation of the family members and caregivers is essential who shall provide home care after discharge from the hospital. So there was a need for preparation and implementation of an educational programme for the bed ridden patients and their care givers.

Other educational aid like models and can be used besides the structured booklet, by the health care providers like nurses and nursing students. The health care personnel in this setting should each contribute their knowledge on education to the caregivers of patients.

Comprehensive pressure ulcer prevention programme are effective in reducing the ulcer incidences rates and this can be cost effective. Hence the booklet is a resource consisting of risk assessment, skin care, offloading and nutrition. Health care personnel are at the forefront of predicting patients at risk of pressure ulcer. Hence workshops may be done at the level of institution to provide hands on training to the nurses who in turn will increase the level of knowledge among caregivers.

As home based \& hospital based care is the most common type of care for immobilized patients. Family education which includes role of caregiver and patients need to be reemphasized to achieve the desired goals.

\section{References}

1. Road accidents in India, 2013, Govt of India, Transport Research Wing; 04-05.

2. Pagadpally G, Murthy P. Venkataramn J : A Clinico epidemiological study of traumatic spine injuries in a rural tertiary care centre in India; Our Experience J. Spinal Research Foundation 2013 : 4(8) : 14-16.

3. Vander Meuler JCH. Present state of knowledge on processes of healing in collagen structures - Int J. of Sports medicine $1982 ; 3: 4-8$

4. Muller E . A. Influence of training of inactivity on muscle strength. Arch Phys 
Medical. Rehabilitation 1970; 51 : 449-

62.

5. Mac Dougall JD, Ward GR Sale DG, Sutton JR : Biochemical adaptation of human sketelal muscle to heavy resistance training and immobilization. J. Appal Physiology 1977; 43 : 700-3.

6. Sarmiento A, Latta LL. Closed functional treatment of fractures. New York : Springer - Verlog. 1981.

7. Spector S A. Simard CP, Fournier M, Sterlicne E Edgerton VR : Architectural alterations of rat hand limb skeletal muscle immobilized at different length. Exp Neurol 1982; 76 : 94- 110.

8. Spence WA, Vallbona C, Carter RE, physiologic concepts of immobilization. Arch Phy Med Rehabilitation; 1965 : 46 : 89-100.

9. Stolor WC, Fry LR, Riddel WM, Weilepp TG Jr. Adhesive forces between muscles fiber and connective tissue in normal and denervated rat skeletal muscle. Arch. Phys. Med Rehabil. 1973; 54; 208-13. 